Bryn Mawr College

Scholarship, Research, and Creative Work at Bryn Mawr College

2014

\title{
Novel Testimony: Alternative Archives in Edwidge Danticat's The Farming of Bones
}

Jennifer Harford Vargas

Bryn Mawr College, jharfordva@brynmawr.edu

Let us know how access to this document benefits you.

Follow this and additional works at: http://repository.brynmawr.edu/engl_pubs

\section{Custom Citation}

J. Harford Vargas, "Novel Testimony: Alternative Archives in Edwidge Danticat's The Farming of Bones," Callaloo 37.5 (2014): $1162-1180$.

This paper is posted at Scholarship, Research, and Creative Work at Bryn Mawr College. http://repository.brynmawr.edu/engl_pubs/18

For more information, please contact repository@brynmawr.edu. 


\title{
NOVEL TESTIMONY Alternative Archives in Edwidge Danticat's The Farming of Bones
}

\author{
by Jennifer Harford Vargas
}

In the famous and haunting scene at the center of One Hundred Years of Solitude (1967), Gabriel García Márquez re-imagines the 1928 United Fruit Company Massacre in Ciénaga, Colombia, from the perspective of the fictional character José Arcadio Segundo Buendía. Having miraculously survived the massacre of the banana company workers, José Arcadio Segundo awakens to find himself on a train full of "man corpses, woman corpses, child corpses who would be thrown in the sea like rejected bananas" (312). Haunted by what he witnesses and justifiably traumatized by the state's subsequent erasure of the massacre from public memory and from the history books with "the official version that nothing had happened," José Arcadio Segundo is brought back from the brink of insanity by befriending Aureliano Babilionia Buendía to whom he imparts his knowledge of the massacre (354). José Arcadio Segundo spends his dying breath entreating Aureliano Babilonia not to forget the events: "Always remember that they were more than three thousand and that they were thrown into the sea" (359). Aureliano Babilonia follows the injunction, sharing the account with his friend Gabriel who, symbolic of Gabriel García Márquez, embodies the possibility that an oral storytelling chain can function as an alternative archive to hegemonic history. García Márquez inscribes this memory into his fictional novel, for before the publication of One Hundred Years of Solitude, the United Fruit Massacre was largely absent from written histories of the region and school textbooks, surviving predominately in local oral accounts. Subsequently, García Márquez's representation of the massacre has come to occupy a prominent place in the Colombian national historical imaginary and has stimulated important recuperative historical work. I bring up the case of One Hundred Years of Solitude because its intervention into the historical archive exemplifies how fictional representations of historical events can function as powerful forms of testimony that critique state violence and mass disappearances.

Edwidge Danticat's 1998 novel The Farming of Bones follows in a long tradition of novels in the Americas that, like One Hundred Years of Solitude, echo José Arcadio Segundo's plea to "Always remember," using the medium of fiction and the novelization of memory to testify against state violence. The Farming of Bones functions as a testimonio or testimony against the genocidal atrocities perpetrated by the dictator Rafael Leónidas Trujillo against ethnic Haitians in the Dominican Republic during the 1937 Parsley Massacre. In this essay, I argue that the novel's aesthetic interweaving of imaginative, documentary, oral, and corporeal modes enriches the testimonial project and stakes a claim for the novel as a testimonial archive. 
Blending creative and documentary forms, The Farming of Bones differs from traditional testimony because it places fiction at the center of its memorial project. Scholarship on testimonio has focused predominately on nonfiction narratives and has traditionally defined testimonio, or testimony, as a first person narrative orally dictated or composed by a subaltern who has witnessed and experienced conditions of exploitation or oppression. The narrative gives an account of the abuses committed against the subaltern and her community as well as an account of their struggles against the conditions of domination. ${ }^{1}$ Such a definition is conceptually constructive when considering a certain kind of narrative production and a particular mode of protest against and documentation of abuses. Yet, imaginative fiction, particularly the novel, has been an important medium through which writers have engaged in the testimonial project, especially when contesting statesponsored violence and social death. ${ }^{2}$ The function of testimony, as I articulate it, is to critique conditions of domination and their ideological justifications. Considering testimony through this critical oppositional function, rather than restricting the boundaries of testimony to nonfiction documentary narratives that relate events witnessed first-hand, illuminates how other narrative modes (such as fiction), other forms of witnessing (such as second- or third-hand hearsay), and other sites (such as the body) produce testimony.

The Farming of Bones valorizes creative forms of testimony as well as oral and corporeal modes of testifying to and passing on histories of oppression, modes that are not conventionally considered authoritative. The novel crafts its testimonial archive by privileging what Diana Taylor terms the "repertoire" in the production of subaltern historical archives. The "repertoire" includes a range of non-scriptural practices, varying from oral stories and gestures to dance, cooking, and ritual prayer (20). Distinct from this "so-called ephemeral repertoire" is the "archive of supposedly enduring materials," which includes written documents, buildings, maps, archeological remains, literary texts, and so on (19). "Archival memory" has traditionally been privileged over the "embodied memory" of the repertoire in the hierarchy of knowledge, granted hegemonic epistemic value, and mythologized as unchanging (19-20). Yet, as Taylor's lengthy study demonstrates and Danticat's novel dramatizes, this Eurocentric model, which delegitimizes many other forms of knowledge production and recording, is not only colonialist but also inaccurate because "[e]mbodied and performed acts [do indeed] generate, record, and transmit knowledge" (21). In The Farming of Bones, the oral stories told by Haitian laborers and the bodies they use to express their testimonies provide accurate testament against the state's repression and disappearances. I argue that the novel enacts the ways in which imaginative, oral, and embodied modes of communicating and recording collectively generate testimonial histories.

In this essay, I trace the production of testimony in The Farming of Bones. Danticat's text stakes a place for novels produced ex post facto by subjects who have not directly experienced state violence but who harness the power of the imagination to recuperate and memorialize subaltern histories. I use Danticat's novel to articulate how fiction both participates in and offers insight into testimonial production against state atrocities. In particular, I analyze how The Farming of Bones contrapuntally fuses documentary realism with prose vignettes and intertwines oral and corporeal narratives in generating a testimonial novel against the Parsley Massacre. The novel as a form thus serves as a rich archival site for counter-hegemonic testimonies. 


\section{A L L A L O O}

\section{Contrapuntal Narrative Modes}

The Farming of Bones chronicles the life of Amabelle Désir during and after the so-called Parsley Massacre of 1937 in which the Dominican dictator Rafael Trujillo ordered the mass murder of Haitians and Haitian Dominicans. Fifteen to twenty thousand Haitians were slaughtered in an operation known in Spanish as el corte (the cutting), in Kreyòl as koutkout- $a$ (the stabbing), and in English as the Parsley Massacre because the Trujillo regime identified ethnic Haitians by their inability to trill the " $r$ " in perejil, the Spanish word for parsley. Narrated by Amabelle, an orphaned Haitian woman working as a domestic laborer in the Dominican Republic, the novel depicts Amabelle's engagement to her lover Sebastien Onius, a migrant Haitian worker at a nearby Dominican sugar cane plantation, and the bloodbath that unfolds around the two lovers. Sebastien is disappeared in a military roundup and Amabelle journeys with their mutual friend Yves to a border town in search of Sebastien where she is subsequently severely abused by the town's Dominican inhabitants but manages to escape into Haiti. The novel goes on to trace Amabelle's postmassacre trials and the physical and psychological trauma she experiences as she slowly rebuilds her life in Haiti, haunted by the violence she has witnessed and by her seemingly doomed search to discover what happened to Sebastien. The novel ends with Amabelle's return to the Dominican-Haitian border where she floats in the shallow water of Massacre River searching for relief and "looking for the dawn" (310).

Imagination, the novel demonstrates, is a deeply enabling organizing structure for consciousness when testifying against authoritarian ideology and repressive violence. If, as Haitian historian Michel-Rolph Trouillot points out, "[h]uman beings participate in history both as actors and as narrators," then it is crucial to consider the narrative modes Amabelle employs in her history-making (2). Two different, contrapuntal modes of narration structure The Farming of Bones: documentary realism and prose vignettes. ${ }^{3}$ Initially, Amabelle uses documentary realism to narrate chronological life events, while she uses prose vignettes to narrate brief images of memories and emotions. The two modes of narrating-which differ in tone, style, and typography - register her different forms of dealing with, witnessing to, accounting for, and processing her and her community's losses.

The overall events Amabelle recounts in what I call documentary realism follow her work in the Duarte household, her increasing awareness of race and class politics, the unfolding events of the Parsley Massacre, and her attempt to live with the unknowns of the past. Amabelle's mode of narrating in these chapters is more traditionally realist and chronological, focusing heavily on detailing actions and events as they progress, on recording conversations, and on chronicling others' experiences. These chapters focus less on Amabelle's interior thought-life and inner turmoil and more on her external life and spoken words. They generate a sense of Amabelle as quiet, observant, loyal, respectful, sensitive, intuitive, compassionate, and deeply concerned about the well-being of others.

In contrast, the stories Amabelle narrates in what I call prose vignettes focus most heavily on intimate and formative moments in her romantic and familial relationships. Many of the chapters have no clear temporal markers and are more heavily symbolic than realist, more oriented towards feelings than events, and more exploratory and associative than documentary and linear. These prose vignettes, to adapt Sonia Saldívar-Hull's vivid description of Sandra Cisneros's The House on Mango Street, are "lyrical and realist" 


\section{A L L A L O O}

combining "the rhythms of poetry and the narrative power of fiction" (87). They give greater interior depth to Amabelle's character and imbue a sense of Amabelle as poetic, haunted, sensual, steeped in metaphor and dreams, creative, reverent of memory, and searchingly complex.

Throughout much of the novel these two starkly different narrative modes are visually distinguished typographically: the realist documentary mode is marked by regular font type, and the prose vignette mode is marked by bold font type. In the first half of the novel, the differing fonts alternate with a chapter in bold type followed by a chapter in regular type. This contrapuntal typographic and stylistic rotation continues for the first half of the novel until Sebastien disappears and Amabelle flees Alegría. In the second half of the novel, all subsequent chapters appear in regular font until the end of the novel when two chapters appear in bold font. Together, the visually marked narrative modes structure the fictional testimony and focalize the communal experience of the massacre via a personal narrative of death and displacement. Amy Novak also analyzes the stylistic distinction as a "point/counterpoint" narrative structure where the chapters that appear in regular font are a "first-person account of the trauma" and those that appear in bold font are "fragments of memories or dreams" (95). Novak contrasts the two styles and contends that the fragments of memory are "spectral" and "disrupt" the first-person narrative thereby interrogating it (95). Rather than read the two styles as at odds, I argue that the two narrative styles first enrich each other in their contrasts, then bleed into each other, and by the end of the novel mutually inflect one another.

The shifting counterpoint between the introspective vignettes and documentary prose is striking and crucial to trace. To some degree the novel's lack of unity in its overall typographic chapter-by-chapter alternations feels like a weakness because the removal of bolded vignette chapters produces an absence in textual richness not entirely filled by the chronological realism. The jarring disappearance of rotating narrative modes is significant, though; the prose vignettes end with Sebastien's disappearance and Amabelle's flight from Alegría in chapter twenty-six, registering the genocidal violence on the formal level of the text. The striking and sudden absence of intimate prose vignettes disrupts the contrapuntal typography and formally reflects the massacre's effects on Amabelle's emotional, psychic, and physical being.

As a result of the dictatorship's mass brutality, the characters in the novel multiply and Amabelle becomes more of a listener than a speaker. During her flight from Alegría, Amabelle meets fellow survivors such as Tibon, Doloritas, and the anonymous people at the border clinic who are apportioned narrative space to relate their differing experiences of the massacre. Chapter twenty-seven, which based on the contrapuntal rotation should be a bolded prose vignette, is instead narrated in documentary realism and contains Tibon's testimony about being forced off a sea cliff at machete-point along with dozens of other people. The chapter ends with Tibon decrying the violence, a "ghostly echo" refracting his words "so that each time Tibon spoke it seemed as though you were hearing many people say the same thing at once" (178). With the departure of stylistic and typographic rotation, a plethora of survivor stories - the "many people" who "say the same thing at once" - subsequently enter the novel.

The novel subsequently shifts away from the typographically split interior life/prose vignettes vs. exterior events / documentary realism toward an inter-subjective and stylis- 


\section{A L L A L O O}

tic fusion. When the prose vignettes return in the novel's final chapters, they now depict a distinctly communal consciousness rather than a strictly individual consciousness. Amabelle recognizes that the "slaughter is the only thing that is mine enough to pass on" (266). In testifying against the Trujillato and passing on the stories of the massacre, she must account for more than her own life; she must also recount the lives of Sebastien, Joël, Wilner, Odette, and Mimi, among others (265). Amabelle begins narrating the final chapter, which is typographically marked in bold font, by calling forth "our testimonials" (281, emphasis added), before she proceeds with an incantatory repetition of "His name is Sebastien Onius" $(281,282) .{ }^{4}$ In her interior life, Amabelle now meditates on her own shadows and hauntings by fusing them with collective losses and disappearances. Similar to the prose vignettes, the realist documentary chapters have also shifted in tone by the end of the novel. Recording Amabelle's internal struggles, the pain of her losses, and her search for reparation, the chapters explore Amabelle's interior life in a reflective manner reserved in the first half of the novel for the bolded prose vignettes. The documentary narrative mode rendered typographically in regular font now represents the socio-political landscape and the landscape of an individual's internal life, just as the bolded vignettes now engage individual and communal grief as well as desires for justice. The nonlinear temporality centered in Amabelle's sensorial, emotional, and psychological interiority enriches and is enriched by the linear chronological temporality based around a series of events in the Duarte household and the Haitian laboring community. By the end of the novel, the personal-collective counterpoint exists simultaneously in each narrative mode.

The significance of the fictional novel's production of narrative testimony against state atrocities resides partially in its contrapuntal aesthetics. Together, the contrapuntal intertwining of story-telling modes produces politically and lyrically charged stories and realist histories. Traditional testimony does not delve deeply into the interior and imaginative life of the testifier because it is restricted by formal and political exigencies for transparency and empirical evidence and because the testifier must recount the events of her oppression, not her emotional reactions to them. ${ }^{5}$ Danticat's novel, in contrast, carves out a place for imaginative modes and stylistic mixture in the testimonial project, offering a more intimate and creative representation of oppression than appears in traditional testimony and asserting the validity of metaphor when recounting trauma at a personal and collective level. ${ }^{6}$ Danticat's contrapuntal narrative structure functions as a politicized aesthetic device. At the same time, the novel situates oral sources and corporeal sites at the center of its testimonial archive.

\section{Hearsay Hermeneutics}

Introspective and intersubjective in its content and its form, The Farming of Bones values hearsay and mediated information in the process of knowledge production and circulation. A prevalent motif in the novel, "talk" functions as a means of knowledge dissemination and as a mode of survival against the dictatorship's genocidal apparatus. The Farming of Bones depicts how the Haitian laborers mobilize their community's oral storytelling tradition initially to warn about the developing massacre and later to process among 


\section{A L L A L O O}

themselves the brutal violence they witness. The novel's representation of hearsay counters the geopolitics of knowledge that denies epistemic validity to the repertoire- that is, to forms of knowledge that are not written down or empirically verifiable. The community's testimonial archive against the massacre is rooted in what I term a hearsay hermeneutics that accurately reads repressive power relations.

Though the novel grants epistemic authority to subaltern communication, the text first dramatizes skepticism vis-à-vis the community's oral exchanges through the narrator Amabelle, who initially doubts the rumors of the developing massacre circulating in the Haitian community. When Señora Duarte invites the Haitian cane laborers into her home for coffee, the workers trade stories in an attempt to decipher the intention behind her uncharacteristic offer, for "[m]any had heard rumors of groups of Haitians being killed in the night" (114). An unnamed woman recounts several killings, relating how "someone there had supposedly witnessed [a murder] with his own eyes" (114). Though the direct sources of these recounted rumors are occluded, many of the workers believe them to be true, asserting that "[r]umors don't start for nothing" (114). Amabelle, however, does not pay them heed, insisting that the "[t]alk of people being killed" is "just talk" and declaring she has "heard too much talk" (125, 126, emphasis added). Though "many" hear the rumors and subsequently pass on the warnings via an oral chain of anonymous tellers-indeed accurately giving warning about what would become known as the Parsley Massacre-Amabelle sees the rumors not as her community's attempt to convey danger and provide protection but as idle gossip. She dismisses the stories as "just talk," much as she dismisses the rumors later communicated to her by a more traditionally valued white source, Doctor Javier.

Amabelle does not initially have an adequate interpretive paradigm to fathom the massacre. She hesitates accepting the warnings partly because she is conscious of the long history of tense racial relations and political conflicts between the Dominican Republic and Haiti: "There were always rumors, rumors of war, of land disputes, of one side of the island planning to invade the other," she maintains adamantly (140). Yet, her dismissal of the truth also signals her naïveté about her social location. When Doctor Javier urges Amabelle to flee Alegría, she thinks incredulously to herself, "It couldn't be real. Rumors, I thought. . . . This could not touch people like me, nor people like Yves, Sebastien, and Kongo who worked in the cane fields. They were giving labor to the land. The Dominicans needed the sugar from the cane" and the money generated by the sale of the commodity (140). Unable to reconcile the threat of violence and displacement with her sense of belonging in the Dominican Republic and her belief in the value of her labor, Amabelle refuses to accept the truth. Mystified about her subordinated position in class, racial, and national hierarchies, Amabelle believes she is a full and invaluable member of the Duarte family and of Dominican society.

Amabelle also doubts that rumors can contain valid knowledge. In response to Doctor Javier's warnings she thinks, "I need to know precisely what was true and what was not. Everything was so strange" (141, emphasis added). While Amabelle partly fears facing the unfolding brutality and feels overwhelmed and disoriented by a sense of powerlessness, she also distrusts orally communicated information that she cannot empirically prove, rationally understand, or personally verify. Amabelle's lack of trust in the community's 


\section{A L L A L O O}

hearsay signals a colonized preference for an identifiable, authoritative source and a disavowal of the hearsay hermeneutics her community employs.

Amabelle's dismissal of the "talk" among the Haitian laborers is particularly compelling given the privileged position oral communication occupies within her community. The Haitian migrants rely on talking

as a way of being joined to your old life [in Haiti] through the presence of another person. At times you could sit for a whole evening with individuals, just listening to their existence unfold, from the house where they were born to the hill where they wanted to be buried. It was their way of returning home, with you as a witness ... This was how people left imprints of themselves in each other's memory. (Danticat 73)

During the interpersonal sharing of one's life, a listener acts "as a witness" in the present so that in the future that witness can carry a message back to the testifier's loved ones, be it material or oral. The act of witnessing and being witnessed to through storytelling creates a transnational culture of mutual responsibility and reciprocity for oral communication among the Haitians. This practice of oral storytelling and witnessing nourishes communities of affect in the Dominican Republic and helps maintain transnational communities of linked fate with those in Haiti, sustaining connections through intimate oral communication. The process of witnessing and being witnessed to is deemed sacred by Father Romain in his sermons to his Haitian congregation as he "often remind[s] everyone of common ties: language, foods, history, carnival, songs, tales, and prayers. His creed was one of memory, how remembering-though sometimes painful-can make you strong" (Danticat 73). Memory communicated through the telling of one's own story or another's story fashions an oral archive that maintains cultural traditions across national borders and provides personal and communal agency. Talking is life-giving and produces an intimate link between talker and listener, testifier and audience. "Talk" that is nourished by intimate interactions and the everyday rituals, the novel suggests, is reliable as an oral chain of communication and as a form of denunciation during times of emergency. For, talking is not only a means to testifying against an injustice but also a vital means of creating and maintaining strong transnational communities of affect and shared fate.

The primacy given to hearsay and talk in the Haitian community also signals that there are multiple positions in a testimonial chain besides the traditionally privileged first-hand witness/testifier and the listener/chronicler. The novel values the multiple degrees of access to information, representing information acquired and passed down second-hand, third-hand, etc. as testimony. Unlike Amabelle, many Haitians in the community respond positively to the hearsay by accepting that the often unidentifiable sources provide trustworthy information and a valid hermeneutic for reading relations of power and repression. The textual performance of skepticism via the conflict between Amabelle's hesitation and the others' acceptance of the rumors exposes the error in discounting oral communication and mediated information as unreliable forms of knowledge generation and circulation. When embedded in intimate relationships and communities of shared fate, hearsay and "talk" are valid oral forms of communicating and narrating violence. 


\section{A L L A L O O}

The novel thus establishes the epistemic power of the repertoire and privileges a hearsay hermeneutics, recognizing that subaltern chains of communication can carry reliable and critical knowledge.

In elevating the Haitian community's oral praxis, the novel structurally modifies testimony's traditional representational paradigm, which is based on synecdoche and empiricism. Amabelle is the narrator and the primary focalizing consciousness for the testimonial novel; yet she strikingly experiences first-hand only a minor portion of the repression that the novel represents. Indeed, the book represents the events of the Parsley Massacre predominantly through the stories that other people such as Tibon and Yves relate directly to Amabelle and through the recounted experiences she overhears in the border clinic and outside the office of the Justice of the Peace. The novel is thus composed of a multi-voiced plethora of stories and experiences that are filtered and collated through Amabelle. While Amabelle's testimonio functions synecdochically, as all testimonies do, the book's multi-storied texture removes part of the synecdochic burden of one individual representing an entire group's experiences. This technique decenters Amabelle as the testifier-narrator and diversifies the experiences represented.

Instead of dominating the testimonial narrative space, Amabelle models attentive listening, especially immediately post-massacre. Incapacitated with other survivors in the border clinic, Amabelle is unable to speak due to her tongue's gross swelling from having parsley forcibly shoved in her mouth. Relegated to the position of listener, Amabelle is witness to the painful testimonials of the anonymous survivors who attempt to process the horrifying experiences they have recently endured. The novel thus represents testimony as a power-laden process initially by dramatizing how one's voice comes at the expense of another's and subsequently by exposing how official paths for documentation and reparation are problematic.

The scene at the border clinic dramatizes the power dynamics that often get eclipsed in testimonies and demonstrates how dialogue and a shared cultural imaginary are crucial for positively negotiating the tension-laden testimonial process. At the border clinic, the community's "talk" has changed from rumor of the developing massacre to tales about the massacre: "As they ate, people gathered in a group to talk. Taking turns, they exchanged tales quickly, the haste in their voices sometimes blurring the words, for greater than their desire to be heard was the hunger to tell" (Danticat 209). Whereas in the previous descriptions of community "talk" people "sit for a whole evening" listening to each other, in this communal "talk" encounter a group of testifiers vie for attention and narrative time. At the outset the testimonial process is driven more by the survivors' "hunger to tell" than by a desire to listen and engage in reciprocal exchange. Talking is an expression of survival and decipherability is less crucial than the simple act of verbally articulating the traumatic experiences.

The group's competitive intersubjective process of witnessing begins with the survivors "taking turns" but doing so impatiently and abruptly. One speaker cuts another stuttering speaker off and "race[s] into his own account without the stutter having completed his" account, while others scream "obscenities ... when something could not be remembered fast enough" (209). Moreover, another "group of voices argu[es] for the right to speak next" and "a voice shout[s] from the other side of the room" as they chaotically vie to tell their stories (209). The survivors narrate tales of loved ones being cut to death by machetes and 


\section{A L L A L O O}

of being shot in the stomach; they relate stories of mass killings in a courtyard and of groups being shoved off a sea pier to their deaths; and they describe memories of awakening in a pit of corpses with vultures attacking the dead bodies. Narrating such atrocities is arduous, and the fierce need to tell their own stories overpowers the witnesses' need to be heard.

The testimonial space is initially not collaborative but competitive: one's voice and narrative space come at the cost of another's. This representation of testimony as competitive and as a process imbued with self-interest exposes the power dynamics involved in the traditional understanding of testimony as synecdochical. While individual testimony does stand in for and represent a collective experience, there is always a gap between the personal and the communal that can only be imaginatively bridged. That is, because the communal experience is composed of a variety of differing but generally common experiences, the particular can never totally stand in for the communal and the voice of one person eclipses other voices. Yet, testimony can also only ever occur in relation-it comes into being in the interaction between a teller and a listener, between a witness and the person being witnessed to. Testimony, therefore, is an intersubjective process at the same time that it is competitive.

As they go through the process of recounting their excruciating experiences, a fragmented vision of the massacre arises from among the anonymous voices and a sense of collective testifying slowly develops. Their experiences resonate and their stories begin to work together. What was once a series of voices interrupting each other becomes voices "echo[ing]" each other and "add[ing]" similar information, as the voices come together from afar to build on each other (Danticat 210, 211). As "everyone chime[s] in" and smiles together at one man's tender memory of his wife, the survivors move from displacing each other's narrative spaces to collaborating on a larger group testimonial (211). The syncopated jiving of separate testimonies becomes a contrapuntal harmonic blending.

The survivors' tension-laden testimonial production moves towards a dialogue, and it is in this dialogic encounter that the productive power of the testimonial process resides. Tellingly, the developing collective narrative coalesces around the Haitian Revolution. One survivor "brag[s] Toussaint L'ouverture's infamous words to his French captors, 'It would take too much to kill me... I'm one of those trees whose roots reach the bottom of the earth. They can cut down my branches, but they will never uproot the tree. The roots are too strong and there are too many'" (Danticat 212). Another speaker correctly identifies the source of the quotation, and as the group draws out Toussaint's relevance to their current situation, a common resistant consciousness begins to emerge. Using the imaginary of the Haitian Revolution, the survivors move away from diegetic narration and toward critical evaluation. Together they assess their current situation:

In those times we had respect. When Dessalines, Toussaint, Henry, when those men walked the earth, we were a strong nation. Those men would go to war to defend our blood. In all this, our so-called president ... says nothing at all to this affront to the children of Dessalines, the children of Toussaint, the children of Henry; he shouts nothing across the river of our blood. (212)

The Haitian Revolution symbolizes active dissent, achieved liberation, and an anti-colonial, anti-racist consciousness. By inserting themselves into this ongoing tradition of resistance 


\section{A L L A L O O}

to and endurance over dominance, they move beyond seeing themselves as disposable and abandoned and toward embracing what Gerald Vizenor has theorized as "survivance," or their active presence and their continual practice of survival. Though they romanticize the liberationists, imagining themselves as children of formidable revolutionaries enables them to articulate their discontent with their current treatment and to claim agency over their stories. For, they must carry the decolonial ideals of the Revolution into the present and "shout" the testimonies of their violations, not rely on the president of Haiti or those in political power to speak for them. Having a common, familiar narrative to rally around enables the survivors to shift from competition to collaboration.

The survivors' collective connection to a narrative of persecution and survivance leads them into a productive dialogic space. The once competitive and fragmented talk turns into a conversation about how to react to the trauma. They debate the actions they chose, the routes they took to survive the killings, and what they could have done differently given that so many were murdered and disappeared while they survived the Parsley Massacre. In so doing, "[ $t$ ]hey looked back and reordered the moments-second vision, hindsight" (Danticat 212). This collaborative reordering of memory, this "second vision" of the past, is the critical heart of the testimonial process. By reconstructing the events, placing them within a historical perspective, and evaluating their responses to the events, the survivors produce knowledge and achieve insight. As they narrate their experiences and reconsider their past actions, their testimonial conversation generates a shift in perspective that helps them envision a way forward.

Storytelling or testimonial "talk" rooted in a Haitian historical consciousness becomes a mode of critical evaluation. In a 2007 interview with Nancy Raquel Mirabal in Callaloo, Edwidge Danticat illumes how integral the Revolution is to the Haitian imaginary:

Often when you meet Haitians they're very mindful of one huge event, such as the Haitian Revolution that happened 200 years ago. But if you hear people talk about it, it's almost as if it happened last year. So the way in which history is not just something in the past, but the way that people carry it forward, the way they live in it, the way they claim it, is very interesting to me. (35, emphasis added)

Positioning their persecution trans-historically, the Revolution puts the community's repression and survivance in perspective and ignites their hunger for liberation from oppression. This allows them to "dream" of their futures in Haiti, tempered by the disillusionment they feel having witnessed the Trujillo regime's genocidal atrocities and having seen the disunity of their people in the face of such shocking brutality (Danticat 213). Though the group at the border clinic does not explicitly produce a unified reading of the massacre or even a consensus about how they should have reacted or how they should move forward, they do produce communally a series of challenging conversations. This process, this movement from competitive storytelling to dialogic interchange, illuminates how an intersubjective testimonial process can facilitate a critical consciousness and generate a dynamic, collaborative, oral testimonial archive.

The novel imagines a resilient testimonial community that survives the Parsley Massacre and subsequently creates and maintains its own memorial archive. The Farming of Bones 


\section{A L L A L O O}

contrasts this intra-community testimony with extra-community testimonial production, elevating informal testimonies among the Haitian community over official testimonies directed at the international community. The testimonial production in the border clinic clashes heavily with the institutional documentation that occurs later in Haiti before the Justice of the Peace and the Church. The novel's representation of institutional modes and sites of testimony interrogates official historical archival production and exposes the inadequacy of State and Church textual recordings of the massacre.

The conditions for official legal recording at the Justice of the Peace are absurdly contradictory: "They ask you to bring papers. They ask you to bring proof," explains Yves (Danticat 231). Demanding official proof or "papers to show that all these people died" is an incongruous and impossible demand because the Dominican state refused to officially recognize the massacre and did not issue death certificates (234). The role of oral testimony is precisely to supply evidentiary proof of the massacre and expose the State's culpability, supplanting (the lack of) written and official documentation with oral documentation. ${ }^{8}$ In demanding that the burden of proof be placed on the victim and in demanding that official, written documents be brought testifying to an event that was not documented by the State but erased by the State, testimony is forced to occupy an impossibly contradictory position, and its empirical, epistemological, and archival value is thereby disavowed.

Neither the State nor the Church is an adequate source of verification or of reparations. As the Justice of the Peace announces he will record no more testimonies, the awaiting witnesses leave dissatisfied, "looking for someone to write their names in a book, and take their story to President Vincent. They wanted a civilian face to concede that what they had witnessed and lived through did truly happen" (Danticat 236). The novel suggests that this belief in institutionalized recording and need for official recognition is misguided. Disillusioned with official paths to and uses of recorded testimony, Yves contests the desire for civilian and clerical authorities to "concede" the reality of the survivors' experiences. He critiques the priests, who "listen and mark down testimonials of the slaughter," declaring: "You tell the story and then it's retold as they wish, written in words you do not understand, in a language that is theirs, and not yours" (246). Yves is weary of this traditional and colonizing form of transcription and dissemination. In contrast, Yves's mother tells Amabelle, "You don't need the justice of the peace ... You don't need a confessor. I, Man Rapadou know your tale" (244). Man Rapadou's words echo the novel's claim about the inability of legal and religious spaces to serve as adequate archives for the massacre. Testimonial communities can grant validation and offer solidarity in the absence of official justice. Rejecting the official mechanisms for post-massacre testimonial production and recording, the novel posits the forging and maintenance of archives from below rooted in community repertoire traditions.

As a testimonial novel, The Farming of Bones functions as a space for subaltern sources and archives, where those marginal to power produce and disseminate effective oral testimony and forge strong and vibrant testimonial communities that endure the conditions of state sponsored massacre and diasporic displacement. As Amabelle announces, "I hear the weight of the river all the time. It creaks beneath the voices. . . It is perhaps the great discomfort of those trying to silence the world to discover that we have voices sealed inside our heads, voices that with each passing day, grow even louder than the clamor of the world outside" (Danticat 266). As these "sealed" voices break out through the medium 


\section{A L L A L O O}

of speech and join with other voices, they emerge as a fictional oral archive that contains the testimonies of the subalterns, unsealing their voices through the novel's text. "The slaughter is the only thing that is mine enough to pass on," Amabelle concludes, and her desire to pass down the stories of the massacre is deeply personal and necessary because it is the only means through which she can memorialize those who have no concrete memorials (266). She seeks "a place to lay it down now again, a safe nest," a space in which victims and survivors can voice their stories and where hers is one of many voices (266). The novel she narrates functions as this imaginative historical and affective archival place for the victims of the Parsley Massacre.

Trouillot has observed of history that "what matters most are the processes and conditions of production of narratives," and examining these processes and conditions reveals "the differential exercise of power that makes some narratives possible and silences others" (25). When institutionalized through hegemonic sites of power such as legal and religious apparatuses, testimony, along with its claims on history and memory, can be purged of its critical epistemic and its reparative potential, not to mention its creative and poetic power. As such, the making and maintenance of alternative archives is necessary to offset the power imbalances in traditional histories. The Farming of Bones grants epistemic authority to oral narratives as well as imaginative narrative modes, which coalesce with corporeal testimony to form The Farming of Bones's novelistic archive.

\section{Corporeal Archives}

As The Farming of Bones centers the body in its testimonial project, the novel's imaginative and oral archives compliment and are contrapuntally enriched by its corporeal archive. While first-hand oral and written narratives are granted precedence in the testimonial tradition, the novel reveals how the body can also effectively testify against oppressive relations. The survivor's body is represented as a material testimony to the massacre. The body is not only the site where violence is physically inscribed, though, for the novel also depicts it as a speaking and knowing text. As I explicate, the novel imagines the body as an expressive and cognitive agent and uses the body to articulate its alternative archival aesthetics.

A vehicle for expression, the body "talks" in Danticat's novel. When Doctor Javier attempts to impress on Amabelle the threat of the developing massacre and the necessity for her escape, he initially pleads with her verbally. Sensing her skepticism, he endeavors to physically communicate the veracity of his statements. As Amabelle narrates, "He was trying to make me see the truth in the pellets of sweat on his face, his knotted brows and hurried gestures urging me to trust him if I wished, believe him if I could" (Danticat 141). Doctor Javier uses his body as an expressive text to testify the truth of the developing mas-

sacre. The visceral intensity of his sweat and the urgency of his concerned and animated gestures serve as signs that physically speak to Amabelle.

At this point in the narrative, Amabelle refuses to listen to the knowledge communicated through Doctor Javier's body, just as she refuses to trust the rumors circulating in her community about the massacre. She dismisses both oral talk and body talk, seeking to "know 


\section{A L L A L O O}

precisely what was true" and to rationally interpret the events (Danticat 141). Tellingly, though, Amabelle physically senses the truth. As she struggles to mentally process the veracity of the massacre, her body offers an epistemologically valid interpretation: "My chest was cramping with a kind of fear I had known only once before, when my parents were drowning: an unstrung feeling as when a gust of wind pushed a door shut behind you, as if to trap you inside" (143). Relaying a sensation of being trapped, her body tells her that the violent events are indeed occurring and the fear beating in her chest, associatively linked to her parents' deaths in the Massacre River years prior, foreshadows the unfolding Parsley Massacre and the deaths Amabelle will soon have to face again at that same river. Though Amabelle herself is at first unable to do so, the novel validates bodily communication and physical intuitions as providing accurate interpretations of external events.

The body in Danticat's novel has the capacity not only to "speak" but also to produce a resistant consciousness vis-à-vis unjust hierarchies of power. Only by paying close attention to the ways in which the text of the body communicates information does Amabelle begin to access what Paula M. L. Moya would call her epistemic privilege and attain critical awareness of her social location. Up to this point, Amabelle has naïvely considered herself to be an integral part of the Duarte family and the socioeconomic structure of the Dominican Republic. Yet, as Moya has demonstrated, "our ability to understand fundamental aspects of our world will depend on our ability to acknowledge and understand the social, political, economic, and epistemic consequences of our own social locations" (43). Increasingly, but to no avail, Sebastien tries verbally to make Amabelle conscious of her racialized and classed position as a black Haitian domestic laborer so that she can recognize her own and her people's exploitation at the hands of rich white Dominicans like the Duartes. Amabelle's demystification finally occurs when she reads Sebastien's hands, which are marked by hard labor. As he angrily accuses her of ignorantly believing that the Duartes will never harm her, Amabelle reaches out for Sebastien's hands clenched tightly in anger: "I reached for the fists and opened them to see the palms where the lifelines had been rubbed away by the cane cutting. Perhaps I had trusted too much ... When the present itself was truly frightful, I had perhaps purposely chosen not to see it" (Danticat 143). Having begun narrating the novel by describing how "the cane stalks have ripped apart most of the skin on [Sebastien's] shiny black face, leaving him with crisscrossed trails of furrowed scars" and how his hands have "lost their lifelines to the machetes that cut the cane," Amabelle is reminded of the physical impact of Sebastien's laboring in the cane fields (1). Though she previously saw Sebastien's missing lifelines, she did not perceive the symbolic implications of this physical erasure. Amabelle goes from seeing Sebastien's scars to reading the stories of his physical exploitation that the marks, as corporeal archives, inscribe. Interpreting the literal erasure of the lifelines on his palms and the associative slow destruction of his life in the cane field economy, Amabelle deciphers his body's text. She thereby begins to question her complicity with the race and class hierarchies and her internalization of the master's rhetoric of protection, finally believing the rumors of the developing massacre.

In enacting the transformation of distrust into trust and in representing Amabelle's moment of achieved awareness via the reading of corporeal archives, the novel fashions a role for the body in the process of consciousness-raising, which connects to the ways in which Sebastien uses body metaphors to interpret and resignify Haitian racialized class 
subordination in the Dominican Republic. The "the farming of bones" or travay tè pou zo as the harvesting of cane is called, is exploitative and physically brutal for Haitian migrant workers (Danticat 55). ${ }^{9}$ The "bones" refer both to the cane stalks and to the harrowing experience of laboring the sugar cane. Extracting sugar from the cane, processing it, and selling it for material profit parallels the way in which the mill owners extract energy from the workers and pay them cheap wages to fuel their own profits. The cane workers "say we're an orphaned people," Sebastien relates to Amabelle, "They say we are the burnt crud at the bottom of the pot. They say some people don't belong anywhere and that's us" (56). Having internalized their class and, implicitly, their racial inferiority, the laborers denigrate themselves as having little worth. Articulating an identity based on the "burnt crud" at the bottom of a pot-a discarded byproduct of cooking lacking in nutrition and taste- the laborers see themselves as not belonging anywhere and as deserving this place of non-belonging at the bottom of the socioeconomic and sociopolitical hierarchy. This turns their social location into an ontology based on dejection and rejection.

According to Sebastien, the body of the farmer of bones must be given an alternative signification, for the metaphors of burnt crud and orphanage naturalize the sense of inferiority that is produced as a result of class and race domination. Significantly, Sebastien mobilizes the metaphorics of the body to produce a decolonial alternative: "I say we are a group of vwayajè, wayfarers. This is why you had to travel this far to meet me, because that is what we are" (Danticat 56). Sebastien exchanges the terms "orphan," "burnt crud," and "not belonging" for the identity of the wayfarer, articulating a different valence for their lives as migrant laborers. His image implies an identity based on a journey since the word "wayfarer" denotes someone traveling on foot. For Sebastien, there is a positive aspect to this journey: the union of two people in love. The farmer of the bones, then, is not an orphan or a subject perpetually relegated to the margins of non-belonging but a person journeying until a belonging can be found through the making of an intimate connection. Since Sebastien expresses this as a group identity-"we are a group of wayfarers" - his imagined community is a community of shared fate undergoing a collective journey. Sebastien even calls the more privileged, home-owning Haitians living in the Dominican Republic "non-vwayajè," or non-wayfarers (68). He thereby turns the wayfarer into the norm and the standard of judgment. In shifting the paradigm for evaluating the harvesters of the cane, Sebastien creates a new signification for their bodies and selves that grants value instead of removing self-worth. Sebastien's insights suggest that the body can help generate resistant knowledge and that the ways in which the body is spoken about in language must be altered as part of the process of contesting oppressive hierarchies and decolonizing both the mind and the body. This reevaluation of the migrant laboring body is crucial to the novel's exploration of Amabelle's developing decolonial consciousness as well as its narration of the Parsley Massacre through oral and corporeal subaltern archives-from the perspectives and bodies of the vwayajè and the violated.

In addition to being a medium for communicating vital information and for generating counter-hegemonic shifts in consciousness, the body in Danticat's novel is represented as a medium for recording injustice. Amabelle's body, forever altered by the massacre, functions as a physical testimony and an archival site to the slaughter. "Now my flesh was simply a map of scars and bruises, a marred testament," muses Amabelle (Danticat 227). The choice of words here-" a marred testament" —is important. As a "testament," 


\section{A L L A L O O}

Amabelle's body is a materialized document, tangible proof of the state-sponsored massacre, which she imparts to her audience. Her body is not a "scarred" testament but a "marred" testament, suggesting its freshly wounded nature. The ambivalence of the description implies that the testament itself is disfigured (marred) and that the injuring (the marring) itself is the testament. Her violated body, then, is a marred form and a form of testimony. As a marred form, the body is physically disfigured in the form of its damaged skin. As a form of testimony, the body's physical evidence of marring functions formally as a witness to the massacre. (Moreover, the formal body of the novel, as we saw earlier, is textually marred by the massacre as the violence interrupts the novel's contrapuntal aesthetic rotation between prose vignettes and documentary realism.) Amabelle's body, then, is the physical archive in which her testimony against the massacre is stored at the same time that it is her testimony.

The novel envisions the body as a residual testimony bearing material witness to past atrocities in the present. Amabelle's flesh is covered in a "map of scars and bruises." In a more literal interpretation, the description suggests that the massacre's effects are both temporarily painful (bruising) and permanent (scarring). In fact, years later, Amabelle's body continues to feel and to relive the massacre. On a symbolic level, the description indicates that the massacre is a present past inscribed cartographically on Amabelle's body. As a "map," the corporeal scars narrate a route; they encode the events of the Parsley Massacre and tell the journey of Amabelle's and her community's violation and their survivance, charting this history on her body and psyche. The body, then, serves as an embodied testament as well as an embodied archive. That is, the survivor's body is a living witness to the Parsley Massacre and a living archive that contains the stories of the massacre. The novel, then, enriches traditional testimonio by insisting on the epistemic and political import of the body, of hearsay, and of aesthetics in the production of testimonial archives.

While they provide enduring evidence to the mass violence, scars also appear throughout the novel: Sebastien's scarred face, Kongo's scarred back, and the community elders who are missing appendages. Post-massacre, Amabelle attempts to decipher the disfigured bodies as texts testifying to the recent atrocities: "I strolled like a ghost through the waking life of the Cap, wondering whenever I saw people with deformities-anything from a broken nose to crippled legs-had they been there?" (Danticat 243). Identifying the precise origin of corporeal disfigurement, I posit, is not as important as recognizing that these marks of disfigurement interlink different forms of violence. Reading Sebastien's scars from laboring in the cane field alongside Amabelle's scars from being beaten during the Parsley Massacre reveals a long legacy of oppression. The fact that before the massacre Amabelle is wounded from her parents' loss and Sebastien from his laboring suggests that the Parsley Massacre is a distinct event and an enormous intensification of domination and should therefore be analyzed alongside other types of violent exploitation and repression Haitians have been subject to historically. In remembering a monumental atrocity such as the Parsley Massacre, the novel links together a series of references to domination thereby refusing to forget French and Spanish colonialism, slavery, US occupations of the island, dictatorships in Hispaniola, and anti-black racism. The novel's trans-historical memory of oppression contextualizes the Parsley Massacre as an atrocity of aberrant magnitude as well as one more incident in the violence-ridden history for Haitians in Hispaniola. ${ }^{10}$ 


\section{A L L A L O O}

The citadel of Henri Christophe that looms throughout the novel is a very different kind of archival monument to the past than the bodies of the survivors. The citadel stands as a testament both to the triumphs of a rebellious slave and to the imbalances of historical production and what Trouillot calls archival power. As an important but traditional historical site, it provides a symbolic space for reflecting on the type of testimonial fiction offered in The Farming of Bones.

The citadel appears at different points in the novel as a sign of strength and protection-a materialized stronghold symbolizing Amabelle's desire for security, which she frequently conjures. Amabelle describes the structure as a "giant citadel" rising above its mountainbase "like two joined fists battling the sky" (Danticat 46). Her association of the monument with defiant fists is based on the oral history passed down to her by her father who recounts the building's origins: “The citadel had been conceived by Henry I, a slave who, after the captives had rebelled against the French and formed their own nation, built forts like the great citadel to keep intruders away" (46). Amabelle's sense of (oral) history celebrates the courageous ex-slave and associates the fortress with the past strength of subalterns who successfully liberated and defended themselves. The simile that analogizes the citadel to a set of fists provides a metaphoric body for the citadel that is deeply resonant with the rest of the novel's body politics, making the citadel a symbolic material embodiment of achieved self-determination and communal liberation.

Only when Amabelle joins a tour of the citadel is her valorization (and romanticization) of the Haitian Revolution's triumphs tempered by an acknowledgement of post-Revolution flaws and, more importantly, by the recognition that the citadel is now a traditional archival site through which historical narratives contingent on erasures are produced. The tourguide resists "vainglory" and insists on being "fair to history" as he recounts the cruelty of Christophe and the thousands of people who died while constructing the citadel (279). In a moment of dramatic irony, the tour-guide declares, "Famous men never truly die ... It is only those nameless and faceless who vanish like smoke into the early morning air" (280). The guide's comments, occurring over the entombed body of Christophe, additionally construct the citadel as the embodiment of a traditional archival monument. The scene is ironic because the tour guide is part of the process of historical production and circulation that centers on "famous men" and excludes non-famous women and men who are designated as "nameless and faceless" despite the fact that they had names and faces. For all of his criticism of Christophe and historical erasures, the guide's tour nevertheless immortalizes a singular figure such as Christophe and disseminates of an archival history rooted in archeological remains such as the citadel monument.

Coming to understand the citadel as a hegemonic archival site gives Amabelle a critical awareness of the gaps in traditional history. Amabelle repeats and revises the tour-guides statement: "Men with names never truly die. It is only the nameless and faceless who vanish like smoke into the early morning air. His name is Sebastien Onius" (Danticat 282). In an incantatory manner Amabelle repeats, "His name is Sebastien Onius," directly responding to the tour-guide's assertion that non-famous individuals vanish into oblivion. Though Sebastien was disappeared in the Parsley Massacre, Amabelle reappears him in the body of her narrative memories as she refuses to allow him to die a nameless death to History. "This past is more like flesh than air; our stories testimonials like the ones never heard by the justice of the peace or the Generalissimo himself," Amabelle movingly muses (281). 
Recalling her earlier statement that her flesh is a map of scars, Amabelle conceptualizes the past in terms of flesh. Crucially, the past is described in the metaphorics of the body; it is personified through a simile and given a body, so to speak. The chain of similes Amabelle expresses is curiously telling. The past is like flesh in the same way that the survivors' stories are like the repertoire of testimonials that went unrecorded. ${ }^{11}$ Recognizing the body's expressive and inscriptive capacities, The Farming of Bones recuperates the physical nature of the past such that the event-driven narratives of traditional history are complemented and made fuller by the novel's imaginative, oral, and corporeal narratives.

The Farming of Bones is filled with the stories of subalterns who no longer "vanish like smoke." The danger of their stories disappearing into "air" is countered by the solidification of the past into flesh-into the bodies of those characters such as Amabelle and into the textual body of the novel. Fiction gives them weight and substance, as they are creatively recorded in the archive of The Farming of Bones, fulfilling testimony's entreaty to always remember.

\section{NOTES}

1. See the most frequently cited definitions of testimonio by John Beverley, George Yúdice, and Casa de las Américas. For classic essays on testimonio, see Jara and Vidal; Gugelberger. For a more recent examination, see Detwiler and Breckenridge. My use of the term subaltern follows these scholars as well as the work of the Latin American Subaltern Studies Group collected in Ileana Rodríguez's edited volume.

2. For Latin American scholarship on the testimonial novel, see Barnet; Craft; Harlow; Poniatowska; Sklodowska; and Zimmerman. For examinations of Latina/o novels through testimonio theory, see Irizarry; Hames-García; Rebolledo; and Saldívar-Hull. In the African American tradition, scholars have studied neo-slave novels within the slave testimony tradition. See Rushdy; Spaulding; and Mitchell. See Patterson's study of slavery as social death and Cacho's examination of racialized rightlessness as social death.

3. Originally a musical term, counterpoint describes the relationship between two or more independent tones or melodies that sound together interdependently and simultaneously in an overall harmonic structure. My theoretical use of counterpoint/ contrapuntal has been influenced by Fernando Ortíz's Contrapunteo cubano and Edward Said's Culture and Imperialism.

4. Significantly, the first line of the novel is "His name is Sebastien Onius" (1). It is traditional in testimonio for the testifier to give her or his name at the outset as an assertion of self. Amabelle's naming of Sebastien rather than her own name signals the novel's inter-subjective representation of multiple experiences of the massacre and its reappearing of the disappeared.

5. The political and aesthetic demand to tell things exactly as they occurred are true both for slave narratives and testimonios, most evident in the politics around prefaces and in controversies that have arisen concerning the veracity and verisimilitude of testimonies. See, for example, Andrews; Dwight A. McBride; Nance; and Arias.

6. Amabelle's prose vignettes initially heavily mobilize metaphor as a mode of narration and meaningmaking. The novel's richest metaphors of shadows, fevers, cloth dolls, sugar women, pigeons, paper lanterns, and rivers are developed in the prose vignettes in the novel's first half, but in the second half they cross over into the realist documentary mode such that these organizing metaphorics link poetic meditation and engaged testimony.

7. This collaborative process normally gets eclipsed in the final, printed testimonial narrative. Predominately, testimonios are crafted by the transcriber/interviewer/compiler out of many conversations and question-answer sessions. The final printed products erase the power hierarchies, the tense interchanges, and the fragmented nature of the conversations between the witness / interviewee and the interviewer.

8. In addition to interrogating the flaws in the evidential demands of the legal apparatus, the novel also exposes the corruption involved in the official testimonial process as those who are able to bribe the soldiers are granted access to the Justice of Peace, while those who cannot must remain (literally 
and symbolically) outside and are eventually denied admittance entirely when the Justice of Peace ceases recording stories.

9. The Parsley Massacre in the novel is inaugurated by the start of a new cane harvest. The novel's titular expression, "the farming of bones," is a dual signifier that indicates the cane workers (those who harvest or farm the bones of sugar cane) and the massacre (the slaughter or farming of Haitian laborers' bones instead of sugar cane). As Shemak so aptly puts it, "'[T] he farming of bones' connotes the back-breaking agricultural labor of the cane fields as well as the slaughter of bodies-a kind of cultivation of death where the machete, the cane cutter's tool, becomes the modus operandi of the massacre" (85).

10. Moreover, as Caminero-Santangelo importantly notes, the novel does not simply blame the dictator Rafael Trujillo or the Dominicans who participated in the Parsley Massacre (though both parties bear responsibility); for the novel assigns "collective culpability" (10) and implicates the Dominican racial imaginary and "the larger national history of racism in which Haitian life is devalued" (12), a history of anti-Haitian racism that continues today in the Dominican Republic.

11. "Testament" comes from the Latin word testari, meaning to be a witness or attest to or to make a will. In legal discourse, a testament is the declaration of one's wishes for the disposal of one's property post-mortem. In a sense, Amabelle's bequeaths her story to the reader. Testimony is also a covenant between God and human kind. In the non-religious sense, testimony forges a kind of covenant or contractual agreement between witness and listener that the recipient of the witness's testimony will share that testimony with others.

\section{WORKS CITED}

Andrews, William L. To Tell a Free Story: The First Century of Afro-American Autobiography. Chicago: U of Illinois P, 1988.

Arias, Arturo. The Rigoberta Menchú Controversy. Minneapolis: U of Minnesota P, 2001.

Barnet, Miguel. "The Documentary Novel." Trans. Paul Bundy and Enrico Mario Santí. Cuban Studies/ Estudios Cubanos 11.1 (1981): 19-32.

—_. "La novela-testimonio: socioliteratura." Unión 6.4 (1969): 99-123.

Beverley, John. Testimonio: On the Politics of Truth. Minneapolis: U of Minnesota P, 2004.

Cacho, Lisa Marie. Social Death: Racialized Rightlessness and the Criminalization of the Unprotected. New York: New York UP, 2012.

Caminero-Santangelo, Marta. "At the Intersection of Trauma and Testimony: Edwidge Danticat's The Farming of Bones." Antipodas 20 (2009): 5-26.

Craft, Linda J. Novels of Testimony and Resistance from Central America. Gainesville: UP of Florida, 1997.

Danticat, Edwidge. The Farming of Bones: A Novel. New York: Penguin Books, 1999.

Detwiler, Louise, and Janis Breckenridge, eds. Pushing the Boundaries of Latin American Testimony. New York: Palgrave Macmillan, 2012.

García Márquez, Gabriel. One Hundred Years of Solitude. Trans. Gregory Rabassa. New York: HarperPerennial, 1991.

Gugelberger, Georg M., ed. The Real Thing:Testimonial Discourse and Latin America. Durham, NC:DukeUP, 1996.

Hames-García, Michael. "Dr. Gonzo's Carnival: The Testimonial Satires of Oscar Zeta Acosta." American Literature 72: 3 (2000): 463-93.

Harlow, Barbara. Resistance Literatures. New York: Methuen, 1987.

Irizarry, Ylce. "The Ethics of Writing the Caribbean: Latina Narrative as Testimonio." LIT 16.3 (2005): 263-84.

Jara, René, and Hernán Vidal, eds. Testimonio y literatura. Minneapolis: Institute for the Study of Ideologies and Literature, 1986.

McBride, Dwight A. Impossible Witnesses: Truth, Abolitionism, and Slave Testimony. New York: New York UP, 2002.

Mirabal, Nancy Raquel. "Dyasporic Appetites and Longings: An Interview with Edwidge Danticat." Callaloo 30.1 (2007): 26-39.

Mitchell, Angelyn. The Freedom to Remember: Narrative, Slavery, and Gender in Contemporary Black Women's Fiction. New Brunswick: Rutgers UP, 2002.

Moya, Paula M. L. Learning from Experience: Minority Identities, Multicultural Struggles. Berkeley: U of California P, 2002.

Nance, Kimberly A. Can Literature Promote Justice?: Trauma Narrative and Social Action in Latin American Testimonio. Nashville, TN: Vanderbilt UP, 2006. 


\section{A L L A L O O}

Novak, Amy. "A Marred Testament: Trauma and Narrative in Danticat's The Farming of Bones." Arizona Quarterly 62.4 (2006): 93-120.

Ortiz, Fernando. Cuban Counterpoint, Tobacco and Sugar. Durham, NC: Duke UP, 1995.

Patterson, Orlando. Slavery and Social Death: A Comparative Study. Cambridge: Harvard UP, 1982.

Poniatowska, Elena. "Hasta no verte Jesús mío." Vuelta 24 (1978): 5-11.

Rebolledo, Tey Diana. Women Singing in the Snow: A Cultural Analysis of Chicana Literature. Tucson: U of Arizona P, 1995.

Rodríguez, Ileana, ed. The Latin American Subaltern Studies Reader. Durham, NC: Duke UP, 2001.

Rushdy, Ashraf H. A. Neo-Slave Narratives: Studies in the Social Logic of a Literary Form. Oxford: Oxford UP, 1999.

Said, Edward. Culture and Imperialism. New York: Alfred A. Knopf, 1993.

Saldívar-Hull, Sonia. Feminism on the Border: Chicana Gender Politics and Literature. Berkeley: U of California P, 2000 .

Shemak, April. "Re-Membering Hispaniola: Edwidge Danticat's The Farming of Bones." Modern Fiction Studies 48.1 (2002): 83-112.

Sklodowska, Elzbieta. Testimonio hispanoamericano: historia, teoría, poética. New York: Peter Lang, 1992.

Spaulding, A. Timothy. Reforming the Past: History, the Fantastic, and the Postmodern Slave Narrative. Columbus: Ohio State UP, 2005.

Taylor, Diana. The Archive and the Repertoire: Performing Cultural Memory in the Americas. Durham, NC: Duke UP, 2003.

Trouillot, Michel-Rolph. Silencing the Past: Power and the Production of History. Boston: Beacon Press, 1995.

Vizenor, Gerald. "Aesthetics of Survivance: Literary Theory and Practice." Survivance: Narratives of Native Presence. Ed. Vizenor. Lincoln: U of Nebraska P, 2008. 1-23.

Yudice, George. "Testimonio and Postmodernism." Latin American Perspectives 18.70 (1991): 15-31.

Zimmerman, Marc. Literature and Resistance in Guatemala: Textual Modes and Cultural Politics from El Señor Presidente to Rigoberta Menchú. Athens: Ohio University Center for International Studies, 1995. 